\title{
Correction to: Exploring the application of machine learning to the assembly line feeding problem
}

\author{
Emilio Moretti $^{1}\left[\right.$ Elena Tappia $^{1} \cdot$ Veronique Limère $^{2,3} \cdot$ Marco Melacini $^{1}$
}

Published online: 6 October 2021

(c) Springer Science+Business Media, LLC, part of Springer Nature 2021

Correction to: Operations Management Research https://doi.org/10.1007/s12063-021-00201-3

In this article all of the author's surnames were listed before their first names on the final publication. Their names should appear as follows:

Emilio Moretti, Elena Tappia, Veronique Limère \& Marco Melacini.

The original article has been corrected.

Publisher's Note Springer Nature remains neutral with regard to jurisdictional claims in published maps and institutional affiliations.

The original article can be found online at https://doi.org/10.1007/ s12063-021-00201-3.

Emilio Moretti

emilio.moretti@polimi.it

1 Department of Management, Economics and Industrial Engineering, Politecnico Di Milano, Milano, Italy

2 Department Business Informatics and Operations Management, Ghent University, Ghent, Belgium

3 Flanders Make, Oude Diestersebaan 133, 3920 Lommel, Belgium 